\title{
AN OPTIMIZED HYBRID SYSTEM MODEL: SOLUTION FOR COASTAL AREA IN BANGLADESH
}

\author{
Subir Ranjan Hazra ${ }^{1}$, Kazi Sakhawat Hossain ${ }^{2}$, Md. Abdullah Al Jubaer ${ }^{3}$, Md. Mortuza Rabby ${ }^{4}$ \\ ${ }^{1}$ M. Sc Student, Dept. of EEE, Dhaka University of Engineering \& Technology, Gazipur, Bangladesh \\ ${ }^{2}$ Project engineer, MAX Group, Dhaka, Bangladesh \\ ${ }^{3}$ M. Sc Student, Dept. of EEE, Dhaka University of Engineering \& Technology, Gazipur, Bangladesh \\ ${ }^{4}$ M. Sc Student, Dept. of EEE, Dhaka University of Engineering \& Technology, Gazipur, Bangladesh
}

\begin{abstract}
As technology is advancing, the consumption of power is steadily rising. Sufficient and reliable source of electricity is a major prerequisite for a sustained and successful economic development and poverty reduction. The development of a country is dependent on the per person energy consumption rate, which is very low in Bangladesh. Bangladesh installed a capacity of 10416 MW electricity on June 2014 and three fourth of which is considered to be accessible. Near about 45\% people has no access to electricity. Therefore, electricity shortage is an acute crisis in Bangladesh. As Saint Martin Island is far away from the main land, it is almost impossible and cost ineffective to supply electricity from the national grid. For connection of nearly 6000 peoples of Saint Martin Island to the main stream of development and to make this island more attractive to the tourists, it is very essential to provide electricity for them. Power generation by combining solar, wind and diesel, known as hybrid system can be the most efficient technique for the electrification of these types of Island. Based on this principle, in this paper a hybrid system is designed for electrification of Saint Martin's Island. In the analysis, realistic data is used for load calculation and optimization analysis for most effective solution. Hybrid Optimization Model for Electric Renewable (HOMER) software is used to find out the final optimization and sensitive analysis of hybrid system. This system satisfies the load demand and reduces carbon emission which will help to generate green energy.
\end{abstract}

Keywords: Electric load, renewable resources, hybrid system, cost of energy, HOMER software

\section{INTRODUCTION}

There are about 30 islands in Bangladesh. The Saint Martin's island $(20.623 \mathrm{~N}, 92.325875 \mathrm{E})$ is a small island in the southernmost part of Bangladesh with $8 \mathrm{~km} 2$ areas. It is about $9 \mathrm{~km}$ south of the incline from the Cox's BazarTeknaf cape. Nearly 6000 populace live there, primarily lived on fishing and on average 4000 tourists visit the island daily from November to March. To meet the increasing tourists demand construction development is booming.

With flourishing concrete structure power demand is also thriving. Now, private parties are operating diesel generators for generation of electricity to the shopping areas at the beachfront of the Uttar Para. The electricity is supplied from 5 PM to 10 PM on a daily rental basis. Some shops and the entire island folks use kerosene lanterns in their houses. Rest of the houses has their own generation of electricity either through solar power or diesel engines. To connect this large amount of poor people to the main stream of development, education and other development facility, this is impossible without electricity. In addition, Saint Martin is one of the beautiful tourist spot in Bangladesh. Tourist based development can change the economic and social development of local residential. The island has a good potential of solar and wind resources. Therefore, for electrification of this Island, in this paper we tried to develop an optimal system from the practical view point. HOMER a simulation software has been used to find out an energy efficient system for this island combining conventional (diesel), renewable (Solar-Wind-Biomass) energy sources. Input information to be endowed with HOMER comprises are: primary load, solar resources, wind resources and biomass resources, cost, constraints, controls etc. The software focused on an optimal configuration to meet the desired electric loads. In journal article [1], data was considered for 100 households and 10 shops. That was the prototype. But, in this analysis, we have tried to design a real system on the basis of present inhabitant and visitors. We have also tried to find out the real outcomes.

\section{HYBRID SYSTEM AND ELECTRIC LOAD}

\subsection{Hybrid System}

Hybrid power system consists of two or more energy conversion devices. In Bangladesh, solar and wind resources are available and it's reliable also. In this analysis, conventional (diesel) source is combined with non conventional resources (solar, wind \& biomass). We have designed the hybrid system to meet the base load with renewable generation and peak load with diesel and biogas generator. The hybrid system consist of an electric load, diesel generators, solar resources, wind resources and other system components such battery, converter [2]. A schematic diagram of standalone hybrid system is represented in Fig-1. 


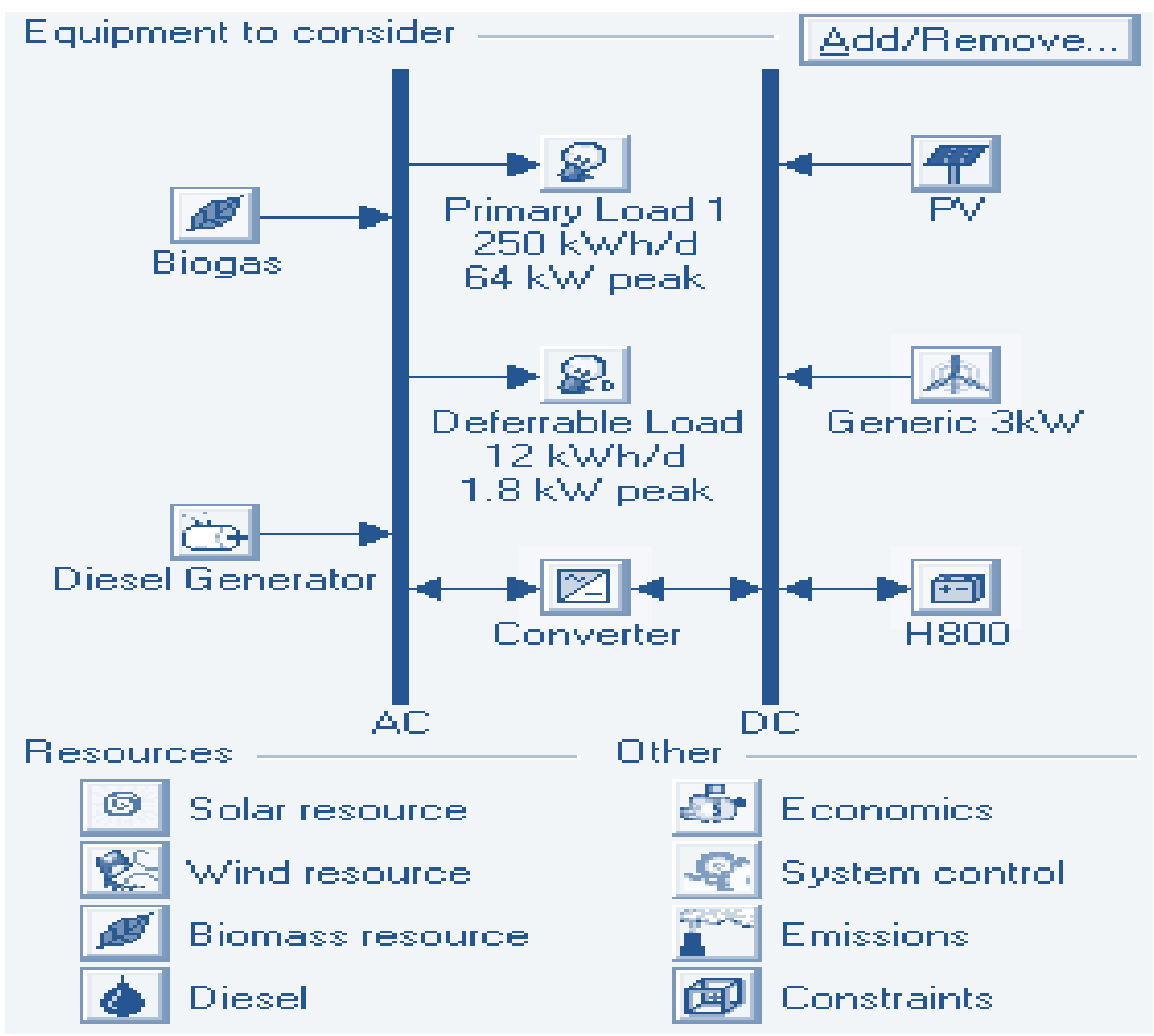

Fig -1: Hybrid energy renewable system

\subsection{Electric Load}

A community of 6000 people, 750 households, 30 shops, 50 tourists based cottage (each has 20 rooms which can accommodate 4 personnel in each room), a school and one health-post has been considered for estimation of electric load. Two energy efficient lamps (CFL, 12W each) for each family are considered. One fan (ceiling fan, 100W) for 300 households each, one television (70W) is considered for 50 households all. Two lights (12W each) and two fans (100W each) are considered for health post and fourteen lights (12W each) and seven fans (100W each) are considered for school. For street lightning, 50 street lights (12W each) are considered. For each shops, two energy saving lamp and a fan is considered. In tourists based cottage, an energy saving lamp (12W) in each room, wash room lamp (5W each) and one TV for each cottage is considered.

Fan load is considered for summer except winter season from evening to next morning for household consumers.

To calculate deferrable load, in this analysis we have considered seven water pumps; one for school and healthpost and the remainder for household consumers. Each water pump has a $150 \mathrm{~W}$ power rating with a pumping capacity of 10 liter/min. The pumps supply 20,000 liter per day for 200 families (primarily considered for 200 households instead of 750 households) as 100 litter per family, and 2000 liter per day for school and clinic. The average deferrable load form April to October is calculated to be $6 \mathrm{kWh} /$ day. In winter (November to March) deferrable load is calculated $21 \mathrm{kWh} /$ day as one water pump $(150 \mathrm{~W}$ each) is considered for each cottage assuming 1,000 litter water demand in each cottage. And overall 5 refrigerators $(1.2 \mathrm{kWh} /$ day each) are considered in load calculations. Load data are synthesized by specifying typical daily load profiles and adding some randomness of $10 \%$ daily. These scaled up the primary load $250 \mathrm{kWh} /$ day with $64 \mathrm{~kW}$ peak and average deferrable load is $12 \mathrm{kWh} /$ day with $1.8 \mathrm{~kW}$ peak annually. Daily load profile is represented for winter in fig- 2 and summer in fig-3. 


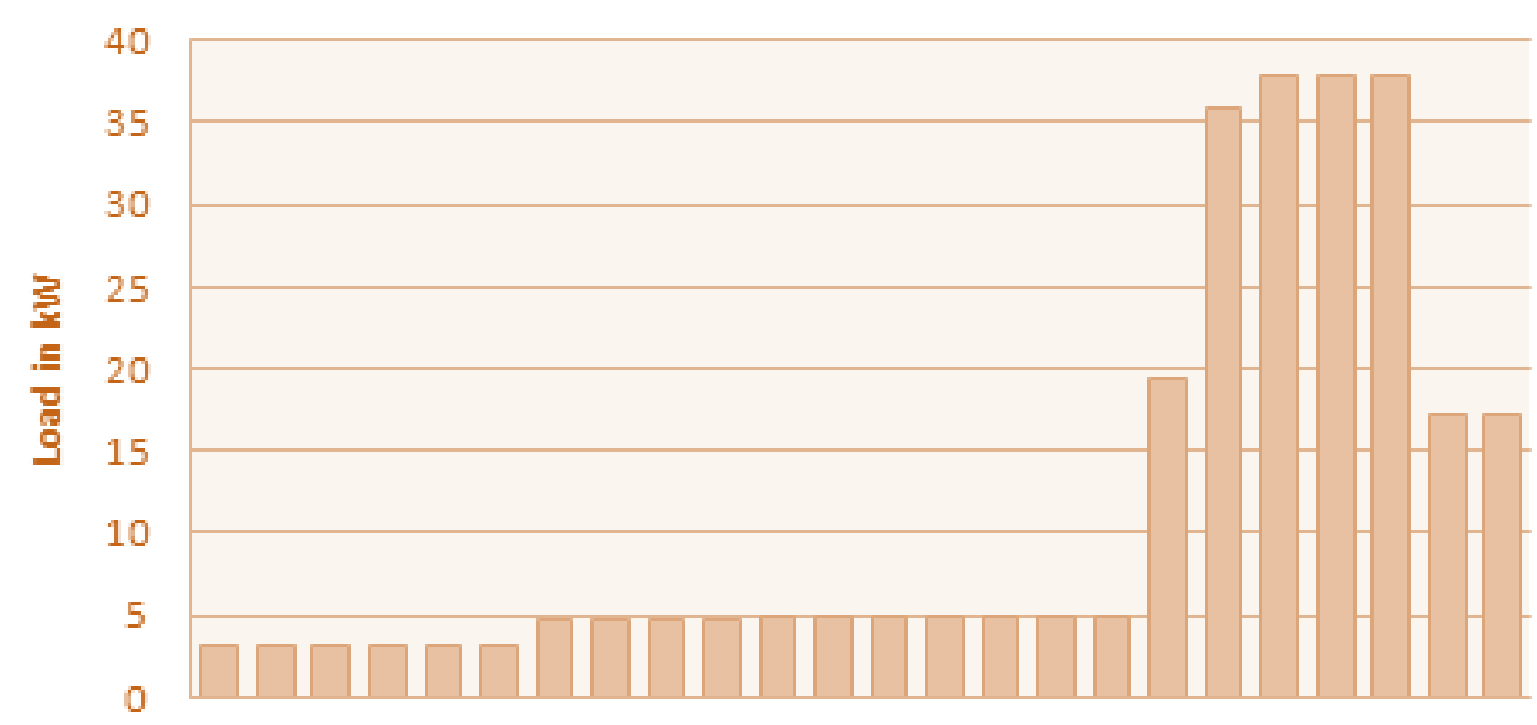

$\begin{array}{lllllllllllll}1 & 2 & 3 & 4 & 5 & 6 & 7 & 8 & 9 & 1011 & 121314151617181920212223 & 24\end{array}$

Time In hour

Fig -2: Load profile on a winter day (November to March)

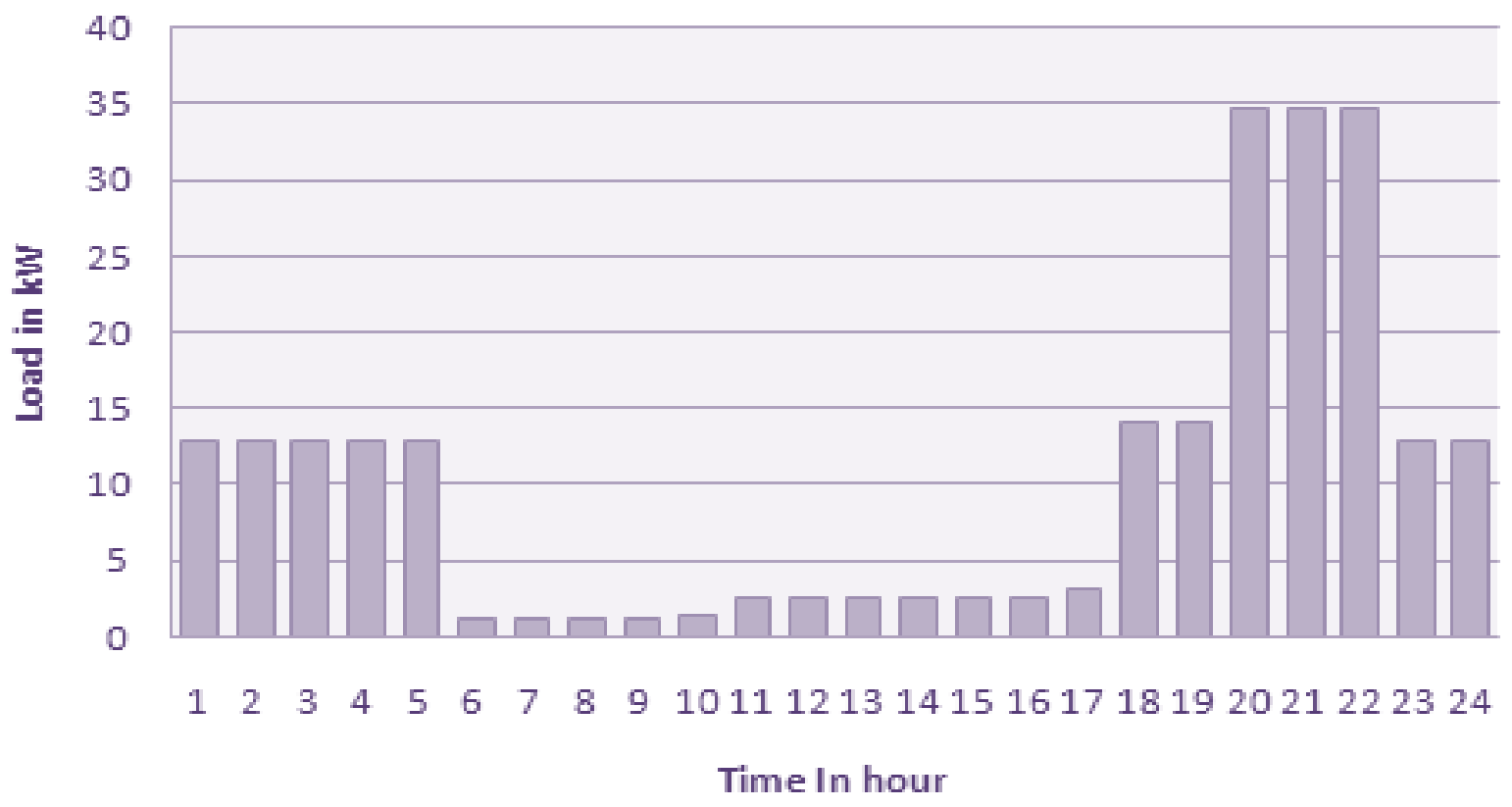

Fig -3: Load profile on a day of summer (April to October)

\section{RENEWABLE ENERGY SOURCES}

\subsection{Solar Energy}

Ground measurement data of solar radiation for the Saint Martin's island is not available. Monthly average global radiation data has been taken by NASA (National Aeronautics and Space Administration) satellite for the period of 1999 to 2001 and estimated value for Teknaf sunshine data, also for 1992 to 2001. German Aerospace Center (DLR) used three years $(2000,2002,2003)$ satellite data for cloud cover, aerosol optical depth, water vapor to calculate Global Horizontal Insulation (GHI) [3] [4]. In this analysis, we have used sunshine data calculate by NASA to estimate the generation of solar system. Table-1 presents the values of monthly solar insulation on horizontal surface for Saint Martin Island.

Table -1: GHI values for Saint Martin Island

\begin{tabular}{|l|l|l|l|}
\hline Months & NASA & Estimated & DLR \\
\hline January & 4.84 & 4.00 & 4.63 \\
\hline February & 5.46 & 4.44 & 5.04 \\
\hline March & 6.41 & 5.37 & 5.62 \\
\hline April & 6.48 & 5.87 & 6.47 \\
\hline May & 5.96 & 5.43 & 4.94 \\
\hline June & 3.6 & 4.01 & 3.39 \\
\hline July & 3.62 & 3.87 & 3.31 \\
\hline
\end{tabular}




\begin{tabular}{|l|l|l|l|} 
August & 3.69 & 3.95 & 3.78 \\
\hline September & 4.34 & 4.09 & 3.96 \\
\hline October & 4.72 & 4.21 & 4.28 \\
\hline November & 4.42 & 3.72 & 4.54 \\
\hline December & 4.54 & 3.75 & 4.16 \\
\hline Average & 4.84 & 4.40 & 4.50 \\
\hline
\end{tabular}

Daily radiation and cleanliness index is graphically characterized in Fig-4 that is obtained from HOMER software by locating the longitudinal and latitude value $\left(20037^{\prime} \mathrm{N}, 92019^{\prime} \mathrm{E}\right)$.

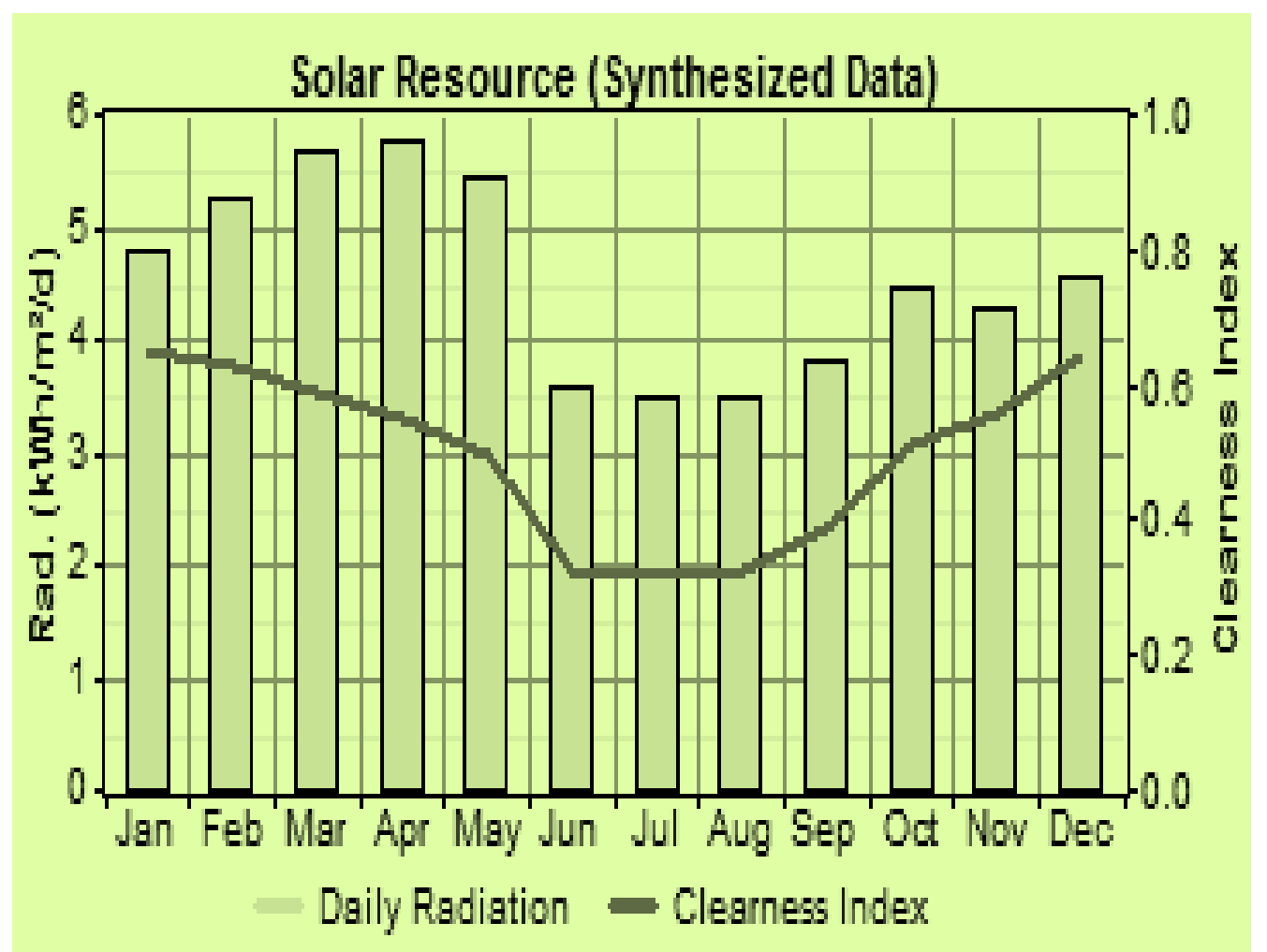

Fig -4: Solar radiation data throughout the year

\subsection{Wind Energy}

A wind resource requires wind speed data. Bangladesh Council for Scientific and Industrial Research (BCSIR) for the period of 1999 to 2001 have measured wind speed at $30 \mathrm{~m}$ height at Saint Martin Island, Bangladesh and NASA measured the values for the same location at $10 \mathrm{~m}$ height. In HOMER, beside wind speed data, few parameters also need to add. In this analysis Weibull factor $(\mathrm{k})$ is taken as 2, autocorrelation factor is considered as 0.78 , the diurnal pattern strength 0.30 is used and the hour of peak wind speed is taken as 14 [5][6][1]. Table-2 shows the monthly averaged measured wind speed at $30 \mathrm{~m}$ height.

Table -2: Monthly average wind speed data for Saint Martin Island

\begin{tabular}{|l|l|l|l|}
\hline Months & NASA(10m) & Measured & V $_{\max }$ \\
\hline January & 3.27 & 5.03 & 23.32 \\
\hline February & 3.39 & 4.70 & 19.78 \\
\hline March & 3.57 & 4.24 & 18.94 \\
\hline April & 3.67 & 3.79 & 20.03 \\
\hline May & 3.89 & 5.07 & 26.30 \\
\hline June & 6.27 & 6.17 & 29.80 \\
\hline July & 6.35 & 5.56 & 24.20 \\
\hline August & 5.64 & 5.78 & 20.40 \\
\hline September & 4.05 & 4.47 & 17.70 \\
\hline
\end{tabular}

\begin{tabular}{|l|l|l|l|} 
October & 3.27 & 4.11 & 15.90 \\
\hline November & 3.24 & 3.53 & 14.50 \\
\hline December & 3.1 & 4.11 & 15.20 \\
\hline Average & 4.14 & 4.71 & 20.51 \\
\hline
\end{tabular}

\subsection{Biomass Resources}

The term biomass encompasses a large variety of materials, including wood from various resources, agricultural residues, and animal and human waste. Bangladesh is an agree-based country and main sources of biomass are agricultural residues. Many different kinds of biomass, such as wood chips, corn, and some types of garbage, are used to produce electricity. Biomass fuel supply usually comes from main three sources viz. Crop residues, animal dung and trees [7]. The available percentage in Bangladesh of different traditional biomass resources are as follows: cow-dung $20.4 \%$, jute stick $7.5 \%$, rice straw $11.6 \%$, rice husk $23.3 \%$, bagasse $3.2 \%$, fire wood $10.4 \%$, twigs and leaves $12.5 \%$, and other wastes $11.1 \%$ [8]. Most of the rural areas cow dung and rice husk is obtainable. In Saint Martin, rice husk is the main biomass resource. 


\section{HYBRID SYSTEM COMPONENTS}

To get the energy efficient and mostly cost effective system, we have tried to design a hybrid system for isolated area. In this hybrid system PV panels, wind turbines, diesel generator, batteries and converters are considered the main components. For economic analysis, capital costs, replacement cost, operation \& maintenance costs, life time, operating hours, number of units and different constraints are defined in HOMER.

\subsection{Biogas Generator}

Electric energy production from biomass demand biogas plant, gas engine generator and other associate devices. To produce $1 \mathrm{~kW}$ energy from biomass demand Tk. 96000 with associate device costs. In this research, a $10 \mathrm{~kW}$ biogas generator is considered. All necessary costs are represented in Table-3.

Table -3: Cost and associates for biogas plant

\begin{tabular}{|l|l|l|}
\hline Parameter & Unit & Value \\
\hline Capital Cost & BDT/kW & 96000 \\
\hline Replacement Cost & BDT/kW & 67200 \\
\hline Operating \& Maintenance Cost & BDT/Yr & 50 \\
\hline Lifetime & Hours & 35000 \\
\hline Load factor & Percent & 15 \\
\hline
\end{tabular}

\subsection{Diesel Generator}

To meet the peak load, diesel generator is used with renewable resources and it's also used the purpose of reserve capacity. We mainly scheduled the diesel generator for the time 6 PM to 12 midnight. In HOMER $10 \mathrm{~kW}$ diesel generators is considered with $10 \mathrm{~kW}$ biogas generators to meet the peak load demand. Diesel generator price is considered by analyzing present market price. Fuel curve slope and intercept are 0.05 and 0.33 respectively [9]. Fuel price is considered here Tk. 68 instead of Tk. 56 which was considered in [1]. Diesel generator data are represented in Table-4.

Table -4: Diesel generator cost assumption and technical parameters

\begin{tabular}{|l|l|l|}
\hline Parameter & Unit & Value \\
\hline Capital Cost & $\mathrm{BDT} / \mathrm{kW}$ & 10000 \\
\hline Replacement Cost & $\mathrm{BDT} / \mathrm{kW}$ & 8000 \\
\hline $\begin{array}{l}\text { Operating \& Maintenance } \\
\text { Cost }\end{array}$ & $\mathrm{BDT} / \mathrm{hr}$ & 30 \\
\hline Operating Lifetime & Hours & 30000 \\
\hline Minimum load ratio & Percent & 10 \\
\hline Fuel Curve Intercept & $1 / \mathrm{h} / \mathrm{kWrated}$ & 0.05 \\
\hline Fuel Curve Slope & $1 / \mathrm{h} / \mathrm{kWrated}$ & 0.33 \\
\hline Fuel Price & $\mathrm{Tk}$ & 68 \\
\hline
\end{tabular}

\subsection{Solar Photovoltaic System}

To mitigate the present energy crisis, Solar Home System (SHS) is presently in useable form in Bangladesh. Rural solvent people are mostly concentrating on SHSs. But, it's generation cost is high and it's not affordable for poor rural residential. By keeping this thing in mind, we have concentrated a system combining conventionalnonconventional hybrid system. Our system requires large set of PV modules. Here, Solar PV cost is considered with installation charges and charge controllers. Charge controllers are used to scheduling when the battery will charge or not. Life time has been taken 25 years. Photovoltaic modules are well thought out $35 \mathrm{~kW}$. Here, derating factor is well thought-out as 80. Considered PV costs with necessary consideration are represented in Table5 .

Table -5: PV cost assumption and technical parameters

\begin{tabular}{|l|l|l|}
\hline Parameter & Unit & Value \\
\hline Capital Cost & BDT/kW & 75000 \\
\hline Replacement Cost & BDT/kW & 66000 \\
\hline $\begin{array}{l}\text { Operating \& } \\
\text { Maintenance Cost }\end{array}$ & BDT/Yr & 100 \\
\hline Lifetime & Years & 25 \\
\hline Derating factor & Percent & 80 \\
\hline Tracking system & No tracking System & 0.05 \\
\hline
\end{tabular}

\subsection{Wind Turbine}

Cost of wind turbine depends on the tower height and technology used. In this analysis, A Generic $3 \mathrm{~kW}$ wind turbine is considered for this hybrid system. Technical and economic parameters [10] of the wind turbine are furnished in Table-6.

Table -6: Wind turbine cost assumption and technical parameters

\begin{tabular}{|l|l|l|}
\hline Parameter & Unit & Value \\
\hline Weibull ( k) & & 2 \\
\hline Autocorrelation factor & & 0.78 \\
\hline Diurnal pattern strength & & 0.3 \\
\hline Hour of peak wind speed & $\mathrm{m} / \mathrm{s}$ & 14 \\
\hline Capital Cost per set & BDT & 600000 \\
\hline Replacement Cost per set & BDT & 450000 \\
\hline Operating \& Maintenance Cost & BDT/Yr & 10000 \\
\hline Lifetime & Years & 25 \\
\hline
\end{tabular}

\subsection{Battery}

In this system, the Hoppecke $8 \mathrm{OPzS}$ storage batteries are utilized [11]. 135 numbers of batteries are considered as charge storage module that will store the charge generated from PV modules is used to find out the cost effective module. A dump load is also considered. A dump load is simply an electrical device (load) to send electricity when the batteries are full or the extra power is not required. Simply the dump load takes the power when the charge controller senses that the batteries are full, to protect them [12]. The specifications and present cost of batteries in real market are represented Table-7. 
Table -7: Battery cost assumption and technical parameters

\begin{tabular}{|l|l|l|}
\hline Parameter & Unit & Value \\
\hline Nominal Voltage & volt & 2 \\
\hline Nominal Capacity & $\mathrm{Ah}(\mathrm{kWh})$ & $800(1.6)$ \\
\hline Maximum Charge Current & $\mathrm{A}$ & 162 \\
\hline Round-trip efficiency & Percent & 86 \\
\hline Minimum State of Charge & Percent & 30 \\
\hline Capital Cost & $\mathrm{BDT} / \mathrm{kWh}$ & 7000 \\
\hline Replacement cost & $\mathrm{BDT} / \mathrm{kWh}$ & 6000 \\
\hline $\begin{array}{l}\text { Operating \& maintenance } \\
\text { Charge }\end{array}$ & $\mathrm{BDT} / \mathrm{kWh} / \mathrm{yr}$ & 50 \\
\hline
\end{tabular}

\subsection{Converter}

As our main load is ac. So, dc to ac converter is used convert the stored energy from battery to ac load and ac to dc converter is also used for charging the battery when excess energy is generated by generators. In this research, $40 \mathrm{~kW}$ converters are considered for the optimum solution. The details of converter are given in Table- 8 .

Table -8: Converter cost assumption and technical parameters

\begin{tabular}{|l|l|l|}
\hline Parameter & Unit & Value \\
\hline Capital Cost & BDT/kW & 15000 \\
\hline Replacement Cost & BDT/kW & 10000 \\
\hline Life time & Years & 15 \\
\hline Efficiency & Percent & 90 \\
\hline Rectifier Capacity & Percent & 95 \\
\hline Rectifier Efficiency & Percent & 85 \\
\hline
\end{tabular}

\subsection{System Control Parameters and Constraints}

The best possible system performance has been carried out by using HOMER software. The software designs an optimal configuration to serve the desired electric loads. For the most favorable analysis, the project life has been considered for 25 years. We have also considered the maximum capacity shortage $1 \%$. System control parameters and various constraints are given in Table-9.

Table -9: System control parameters and constraints

\begin{tabular}{|l|l|}
\hline Parameter & Value \\
\hline Percent of annual peak load & 0 \\
\hline Percent of hourly load & 10 \\
\hline Percent of hourly solar output & 0 \\
\hline Percent of hourly wind output & 35 \\
\hline Maximum Unreserved energy & $0(\%)$ \\
\hline Maximum renewable fraction & 0 to $100 \%$ \\
\hline Maximum battery life & N/A \\
\hline Maximum annual capacity shortage & 0 and $1 \%$ \\
\hline
\end{tabular}

\section{RESULTS AND DISCUSSIONS}

The systems performance analysis has been carried out by using HOMER software. The optimized result is analyzed for specific wind speed $4.72 \mathrm{~m} / \mathrm{s}$, solar irradiation $4.55 \mathrm{kWh} / \mathrm{m} 2 / \mathrm{d}$ and diesel price 68 taka. The hybrid system analyzed for $35 \mathrm{~kW}$ PV array, one $3 \mathrm{~kW}$ Generic wind turbine, $10 \mathrm{~kW}$ diesel generator, $10 \mathrm{~kW}$ biogas generator and 135 no of storage batteries with $40 \mathrm{~kW}$ converters. Fig. 5 represents the capital cost of the analyzed system is $5,822,000 \mathrm{BDT}$, replacement cost is 3,169,998BDT, operation and maintenance charge is 5,654,494BDT, fuel cost is $4,920,803 \mathrm{BDT}$. Here, considering the salvage value, the system search out a minimum NPC of Tk. 19,330,286 represented in Fig-5.

Net Present Costs
\begin{tabular}{|l|r|r|r|r|r|r|}
\hline \multirow{2}{*}{ Component } & Capital & Replacement & \multicolumn{1}{c|}{ 0\&M } & Fuel & Salvage & Total \\
\cline { 2 - 8 } & \multicolumn{1}{c|}{$(\$)$} & \multicolumn{1}{c|}{$(\$)$} & \multicolumn{1}{c|}{$(\$)$} & $(\$)$ & \multicolumn{1}{c|}{$(\$)$} & \multicolumn{1}{c|}{$(\$)$} \\
\hline PV & $2,450,000$ & 0 & 1,409 & 0 & 0 & $2,451,410$ \\
\hline Generic 3kW & 200,000 & 56,533 & 140,940 & 0 & $-33,222$ & 364,251 \\
\hline Biogas & 960,000 & $1,470,994$ & $4,354,326$ & 0 & $-121,222$ & $6,664,098$ \\
\hline Diesel Generator & 100,000 & 32,806 & $1,157,113$ & $4,920,803$ & $-14,923$ & $6,195,799$ \\
\hline Hoppecke 8 OPzS 800 & $1,512,000$ & $1,417,258$ & 705 & 0 & $-28,267$ & $2,901,696$ \\
\hline Converter & 600,000 & 192,407 & 0 & 0 & $-39,374$ & 753,033 \\
\hline System & $5,822,000$ & $3,169,998$ & $5,654,494$ & $4,920,803$ & $-237,007$ & $19,330,286$ \\
\hline
\end{tabular}

*All the currency values are considered in terms of Tk. (Taka, Bangladeshi Currency) instead of \$(USD).

Fig -5: Net present cost of the proposed system 
The overview of electrical parameters in our analysis is represented in Fig-6. The figure shows that the ac primary load demand is $95 \%$ and deferrable load demand is 5\%. And demand is achieved with $42 \%$ PV generation, $2 \%$ wind generation, $45 \%$ from biogas and rest $12 \%$ from diesel generator. It's possible to consider a smaller diesel generator. But, we considered a $10 \mathrm{~kW}$ generator in case of biogas generator failure. Simulated result shows that the minimum Cost of Energy (COE) [13] is tk.14.351/kWh that was tk. 26.54 in [1]. In this analysis, renewable fraction is obtained $0.884 \%$ and annual capacity shortage is $0.3 \%$ only.

\begin{tabular}{|c|c|c|c|c|c|}
\hline \multicolumn{6}{|l|}{ System Architecture: } \\
\hline \multicolumn{6}{|c|}{$\begin{array}{l}35 \mathrm{~kW} \text { PV } \quad 10 \mathrm{~kW} \text { Diesel Generator } 40 \mathrm{~kW} \text { Rectifier T } \\
1 \text { Generic } 3 \mathrm{~kW} 135 \text { Hoppecke } 80 \mathrm{Pz} 580 \mathrm{Cycle} \text { Charging Le } \\
10 \mathrm{~kW} \text { Biogas } 40 \mathrm{~kW} \text { Inverter }\end{array}$} \\
\hline \multicolumn{6}{|l|}{ Electrical } \\
\hline Production & $\mathrm{kWh} / \mathrm{yr}$ & $\%$ & Quantity & $\mathrm{kWh} / \mathrm{yr}$ & $\%$ \\
\hline PV array & 54,775 & 42 & Excess electricity & 20,916 & 15.9 \\
\hline Wind turbine & 2,696 & 2 & Unmet electric load & 154 & 0.2 \\
\hline Biogas & 58,611 & 45 & Capacity shortage & 295 & 0.3 \\
\hline Diesel Generator & 15,283 & 12 & Ouantitu & \multicolumn{2}{|c|}{ Value } \\
\hline Total & 131,365 & 100 & Renewable fraction & & 0.884 \\
\hline Consumption & $\mathrm{kWh} / \mathrm{yr}$ & $\%$ & & & \\
\hline AC primary load & 91,123 & 95 & & & \\
\hline Deferrable load & 4,445 & 5 & & & \\
\hline Total & 95,569 & 100 & & & \\
\hline
\end{tabular}

Fig -6: Energy generated by diesel generator, PV system and wind Turbine

\section{SENSITIVE ANALYSIS}

In this paper sensitive analysis has been embark on study the effects of variation in solar radiation and diesel price for Levelized Cost of Energy (COE) [1]. This sensitive analysis is done for the future forecasting of price for unit generation with the increase and decrease of diesel price. In Fig. 7, we find COE is Tk. $14.4 / \mathrm{kWh}$ at the point of solar irradiation $4.55 \mathrm{kWh} / \mathrm{m} 2 / \mathrm{d}$ and diesel price Tk. 68. If diesel price increases, COE will be increased. As for example, at $4.55 \mathrm{kWh} / \mathrm{m} 2 / \mathrm{d}$ solar irradiation and diesel price Tk. 70, COE will be 15 taka. The Levelized cost of energy is signified in Fig-7.

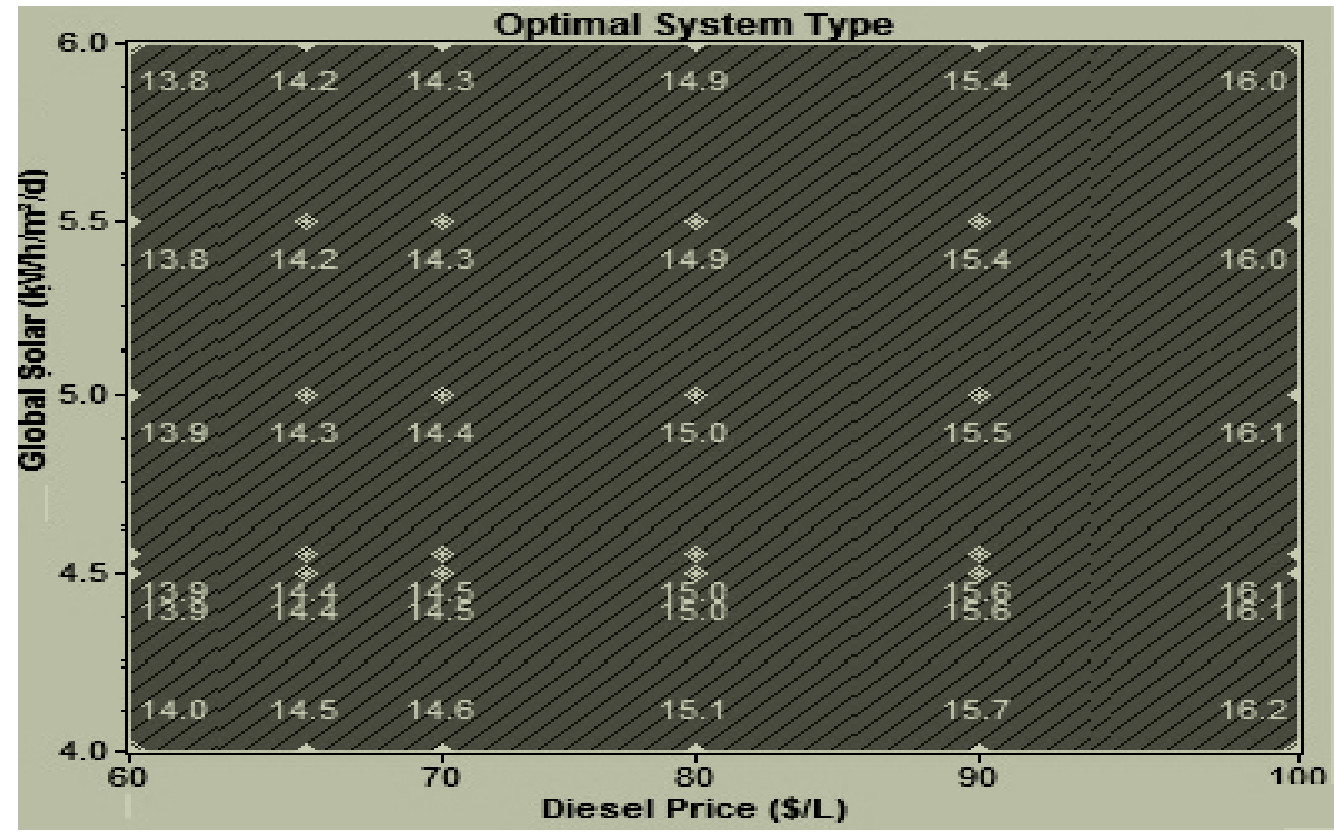

Fig -7: Optimal system in terms of diesel price and solar radiation 


\section{CONCLUSION}

In our country most eclectic generation is dependent on natural gas. The reserve of natural gas is running off, other fossil fuels have to import from abroad. The price of fuel is increasing throughout the world. Though, Government has set up his goal to go under coverage of electricity of the whole country within 2030 and already taken few initiatives to solve the power crisis. However, that's not enough to fulfill the present crying need. Nevertheless, it may not possible to fulfill the target within that time because now nearly $60 \%$ people in rural area have no access to the national grid and around $75 \%$ Bangladeshi of 161 million citizens live in rural areas. Therefore, this type of proposed system can be a solution for rural area in addition to the isolated island. The feasible system is considered $35 \mathrm{~kW} \mathrm{PV}$ array with one $3 \mathrm{~kW}$ Generic wind turbine, a $10 \mathrm{~kW}$ diesel generator, a $10 \mathrm{~kW}$ biogas generator and 135 storage batteries among $40 \mathrm{~kW}$ converter. The cost of energy of the proposed model is found 14.351 BDT, which is around 20 to 25 taka at present solar home system generation cost. As the net present cost is high, a large capital is needed for the feasibility of this research. But, it is possible to make up the establishment cost within 10 years. So, this project can be profitable though the preliminary set up cost is high. The integrated of the proposed model with the grid connection is also possible. The use of hybrid power system not only reduces the unit price of electricity generation but also generate environmental friendly energy.

\section{REFERENCES}

[1]. A. K. M. S. Islam, M. M. Rahman, M. Alam, H. Mondal and F. Alam, "Hybrid energy system for St. Martin Island, Bangladesh; an optimized modeling proceeding." Evolving Energy-IEF International Energy Congress (IEF-IEC2012); vol. 49, pp. 179-188, 2012.

[2]. G. M. Shafiullah, M. T. Amanullah, "Economic analysis of hybrid renewable model for subtropical climate." Int. Journal of thermal and Environmental Engineering, vol. 1, pp. 57-65, 2010.

[3]. High Resolution Solar Radiation Assessment for Bangladesh, SWERA project. URL: http://swera.unep.net

[4]. NASA surface meteorology and solar energy, released 5.1, http://eosweb,larc.nasa.gov

[5]. A. Demiroren, U. Yilmaz, "Analysis of change in electric energy cost using renewable energy sources in Gokceada, Turkey: an island example." Renew Sustain Energy rev, vol. 14, pp. 323-33, 2010.

[6]. K. Q. Nandi, "A wind-PV-battery hybrid power system at Sitakunda Bangladesh." Energy Policy 2009, vol. 37, pp. 3659-64, 2005.

[7]. M. Ahiduzzaman, "Rice Husk Energy Technologies in Bangladesh" Agricultural Engineering International: the CIGR Ejournal. Invited Overview No. 1. Vol. IX, 2007.

[8]. M. S. Islam and T. Mondal, "Potentiality of Biomass Energy for Electricity Generation in Bangladesh." Asian Journal of Applied Science and Engineering, vol. 2, no. 2, pp.103-110, 2013.
[9]. K. Q. Nguyen, "Long term optimization of energy supply and demand in Vietnam with special reference to the potential of renewable energy." Germany: University of Oldenburg, 2005.

[10]. M. S. Kaiser and S. K. Khadem, "Energy efficient system for St. Martin's island of Bangladesh.” proceeding of the Journal of Engineering and Applied Sciences, vol. 1, pp. 93-97, 2006.

[11]. A. H. Mondal and M. Denich, "Hybrid system for decentralized power generation in Bangladesh." Energy for Sustainable Development; vol. 14, pp. 48-55, 2010.

[12]. BD Charge Controller website. URL: http://www.bdchargecontroller.com.

[13]. S. S. M. Shaahid, El-Amin, "Techno economic evaluation of off-grid hybrid photovoltaic-diesel-battery power system for rural electrification in Saudi Arabia- a way forward for sustainable development." Renew Sustain Energy Rev; vol. 13, pp. 625-33, 2009.

\section{BIOGRAPHIES}

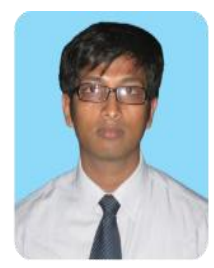

Subir Ranjan Hazra was born in Barisal, Bangladesh on 25th July, 1985. He obtained his B.Sc. in Electrical and Electronic Engineering from Stamford University, Bangladesh in 2008. Currently he is pursuing his post graduate study under the department of Electrical \& Electronic Engineering in Dhaka University of Engineering and Technology; Bangladesh. His research interests include Power System and Renewable Energy.

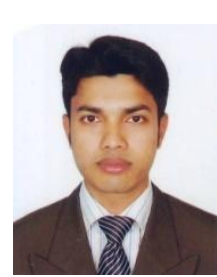

Engr. Kazi Sakhawat Hossain was born in Comilla, Bangladesh on 19th December, 1984. He obtained his B.Sc. in Electrical and Electronic Engineering from Ahsanullah University of Science and Technology, in 2009. At present he is working at Max Group as a project Engineer. His research interests include RF Engineering, Power System and Renewable Energy. Engr. Kazi Sakhawat Hossain is a member of Institution of Engineers of Bangladesh (IEB).

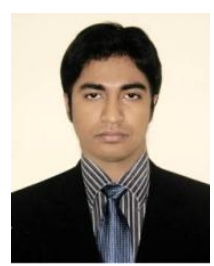

Md. Abdullah Al Jubaer was born in Dhaka, Bangladesh on 15th February, 1989. Currently he is pursuing his post graduate study under the department of Electrical \& Electronic Engineering (EEE) in Dhaka University of Engineering and Technology (DUET), Bangladesh and doing job as an Engineer in Zaber \& Zubair Fabrics Ltd (Noman Group of Industries, Bangladesh). He obtained his B. Sc Engineering Degree in Electrical and Electronic Engineering from International Islamic University of Chittagong (IIUC) in 2009. His research interests include Power System Engineering, and Renewable Energy. 
Md.Mortuza Rabby was born in

Dinazpur, Bangladesh on 17th November, 1985. He obtained his B.Sc. in Electrical and Electronic Engineering from Stamford University, Bangladesh in 2010. Currently he is pursuing his post graduate study under the department of Electrical \& Electronic Engineering in Dhaka University of Engineering and Technology; Bangladesh. His research interests include Power System, Power Electronics and Renewable Energy. 